\title{
COXEN Score 39
}

National Cancer Institute

\section{Source}

National Cancer Institute. COXEN Score 39. NCI Thesaurus. Code C128236.

A score of 39 on the COXEN Sensitivity Scale. 